\title{
Persistent Infection of Three Salmonid Cell Lines with Infectious Pancreatic Necrosis Virus (IPNV)
}

\author{
R. P. Hedrick and J. L. Fryer \\ Department of Microbiology, Oregon State University, Corvallis, Oregon 97331, U.S.A.
}

\begin{abstract}
Persistent infections were established with infectious pancreatic necrosis virus (IPNV) in chinook salmon (CHSE-214), steelhead trout (STE-137) and in rainbow trout (RTG-2) cell lines. Viral persistence was characterized by the release of infectious virus, positive immunofluorescence, resistance to superinfection with homologous virus and susceptibility to challenges with heterologous viruses.

The morphology and growth characteristics of persistently infected (PI) and uninfected cell lines was indistinguishable. PI CHSE-214 and STE-137 cell lines produce little or no interferon. Activity suggesting interferon was detected in culture fluids from PI RTG-2 cells.

Temperature-sensitive virus was not detected in the culture fluids of PI CHSE-214 or STE-137 cell lines and the RTG-2 line has not been tested. Virus in the culture fluids of both PI STE-137 and RTG-2 cell lines demonstrated autointerference when inoculated onto uninfected control cells. The autointerfering component from PI STE-137 cells was removed from the culture fluid by ultracentrifugation and had a bouyant density of $1.29 \mathrm{~g} / \mathrm{cc}$ in a cesium chloride gradient. Infectious virus also produced by PI STE- 137 cells had a density of $1.33 \mathrm{~g} / \mathrm{cc}$. The production of defective interfering (DI) virus during viral persistence was further supported by electron microscopic examination of PI STE-137 cells. The production of DI virus by PI STE-137 cells as well as interferon in the PI RTG-2 cells were proposed as two mechanisms by which the cytocidal course of infection in these cell lines is prevented.
\end{abstract}

Persistent infections in cell cultures have been established with representatives of most of the major taxonomic groups of RNA viruses (RIMA and MARTIN, 1976). Viral persistence in these cultures is characterized by continued growth and division of the cells in the presence of a virus which is ordinarily cytocidal. Examinations of persistently infected cells have revealed that the mechanisms which control viral persistence in vitro may also function during infections in the intact host (HuANG and BALTIMORE, 1970).

At least three mechanisms have been proposed for the maintenance of viral persistence in cell cultures (JoKLIK, 1977). The production of interferon by certain persistently infected cell lines is known to control the cytopathic effects which accompany virus production (SEKELlick and MARCus, 1978). The selection of mutant virus, in particular temperature-sensitive (ts) viruses has been shown to be important in the maintenance of persistent infections with several RNA viruses (PREBLE and YoungNeR, 1975). The integration of provirus into the host cell chromosome has been pro- posed as a mechanism by which certain RNA viruses (not belonging to the retroviridae) may maintain viral persistence (ZHADNOV, 1975; SiMPson and IINUMA, 1975).

Infectious pancreatic necrosis virus (IPNV) is an icosahedral shaped virus with a genome consisting of two segments of double-stranded RNA (DoBos, 1976). This virus replicates well in several cell lines derived from fish tissues (WoLF and MANN, 1980) causing characteristic cytopathic effects after two to three days at $16^{\circ} \mathrm{C}$. Persistent infection of the chinook salmon embryonic (CHSE-214) cell line with IPNV has been reported by AHNe (1977), HedRICK et al. (1978a) and MACDONALD and KenNedy (1979). Viral persistence in all three studies was characterized by the production of infectious virus (detected in the culture fluids), resistance to superinfection with IPNV and susceptibility to infection with heterologous viruses.

The persistent nature of IPNV infection in brook (Salvelinus fontinalis) and rainbow (Salmo gairdneri) trout has been described by BuLli and WolF 
(1969), Yamamoto (1975) and Reno et al. (1978). The relationship between the virus and host that results in the establishment and maintenance of the carrier state in these trout is not understood. The characteristics that cell lines persistently in fected with IPNV share with carrier brook trout have been emphasized in a previous report (HEDRICK et al., 1981, in press). The purpose of our studies with persistently infected cell lines has been to: (1) determine which mechanism(s) control viral persistence in vitro, (2) to estimate the influence of the host cell species on the nature of persistence and (3) to examine carrier trout for the same virushost cell interactions.

\section{Materials and Methods}

\section{Cell Lines}

The chinook salmon (CHSE-214) and steelhead trout (STE-137) lines derived from embryonic tissues (FrYer et al., 1965) and the rainbow trout gonad (RTG-2) (Wolf and Quimby, 1962) were used in this study. The cells were propagated as monolayers in plastic flasks (Corning) at $16^{\circ} \mathrm{C}$ in Eagle s minimal essential medium (MEM) with Earle's salts (Flow Laboratories) supplemented with either $5 \%$ (MEM-5) or $10 \%($ MEM-10) fetal calf serum, penicillin (100 I. U./ml) and streptomycin $(100 \mu \mathrm{g} / \mathrm{ml})$.

\section{Viruses}

The Cascade Locks (CL) strain of IPNV isolated from coho salmon (Oncorhynchus kisutch) was used to establish persistent infections. Virus prepared by repeated plaque purifications was held at $-70^{\circ} \mathrm{C}$ as stock CL-IPNV.

Infectious hematopoietic necrosis virus (IHNV) (Mulcahy, 1977), Herpesvirus salmonis (Wolf et al., 1978) and chum salmon virus (CSV) (J. R. WiNTON, personal communication) were used to test the susceptibility of persistently infected (PI) cell lines to heterologous viruses.

\section{Virus Titrations}

Virus concentrations in the culture fluids of infected cells were determined by $\mathrm{TCID}_{50}$ analysis or plaque assay using either methylcellulose (Fischer Co.) or agarose (Bio Products) as the solid overlay. The method for plaquing fish viruses are those described by Wolf and QuimBY (1973).

\section{Immunoflorescence}

The indirect immunofluorescence method was used to examine lytically and persistently infected cells for the presence of IPNV antigens. The procedure for staining these cells was similar to that of Tu et al. (1974). Goat anti-rabbit serum labeled with either tetramethylrhodamine isothiocyanate or fluorescein isothiocyanate (Baltimore Biological Laboratories) was reacted with bound rabbit anti-IPNV serum. Cells were observed with a fluorescent microscope (Carl Zeiss Inc.) equipped with a $200 \mathrm{~W}$ mercury lamp.

\section{Interferon Determinations}

The culture fluids of PI cell lines were assayed for interferon activity by the plaque reduction technique as described by SEkELlick and MARCus (1978). Infectious virus which was present in the culture fluids from PI cell lines was removed by centrifugation at $100,000 \times g$ for $2 \mathrm{~h}$ prior to each interferon assay. Culture fluids from uninfected cells served as controls.

\section{Temperature Experiments}

The effect of elevating the propagation temperature of PI cell lines on the production of virus was tested by a modification of the method of YounGNER et al. (1976). Persistently infected cells were seeded into $25 \mathrm{~cm}^{2}$ flasks $\left(5 \times 10^{5}\right.$ cells $)$ and incubated at either 16 or $22^{\circ} \mathrm{C}$. After 9 days, the cells were counted and the culture fluids were titrated for infectious virus by TCID $_{50}$ analysis at both 16 and $22^{\circ} \mathrm{C}$

Virus in the culture fluids from control cells infected with stock CL-IPNV was titrated after 3 days of incubation at either 16 or $22^{\circ} \mathrm{C}$. The concentrations of virus in culture fluids from PI and lytically infected cells were standardized to $10^{6}$ cells. All TCID $_{60}$ values represent the geometric mean of duplicate titrations.

\section{Results}

Morphology and Growth Characteristics of PI Cell Lines

The morphology of cells in PI lines was indistinguishable from that of uninfected cells (Fig. 1). The morphology of PI cells was not altered by challenges with stock CL-IPNV. Uninfected and PI cell lines had similar growth characteristics at 

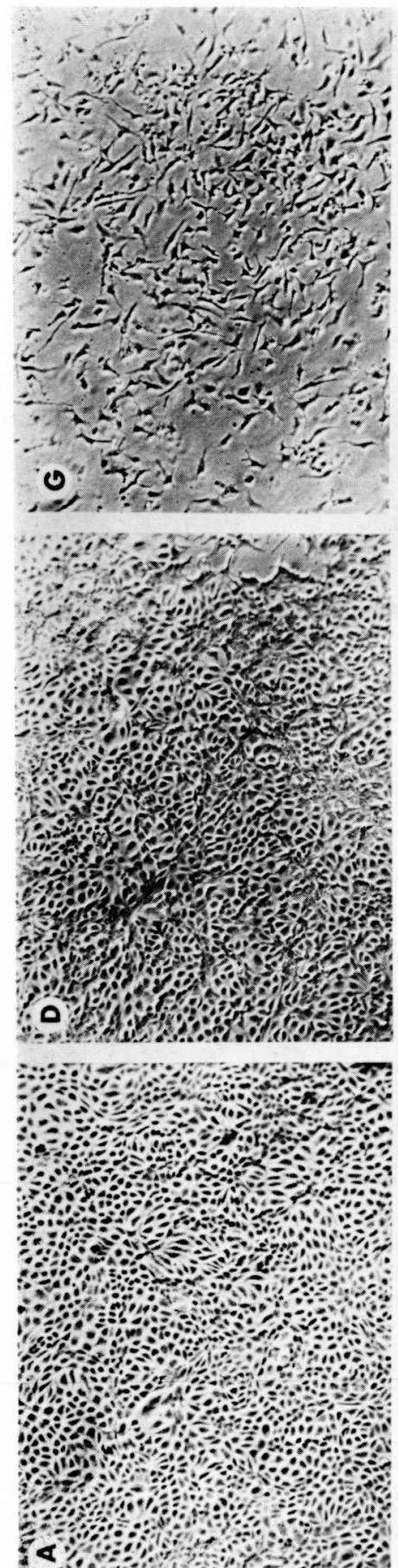
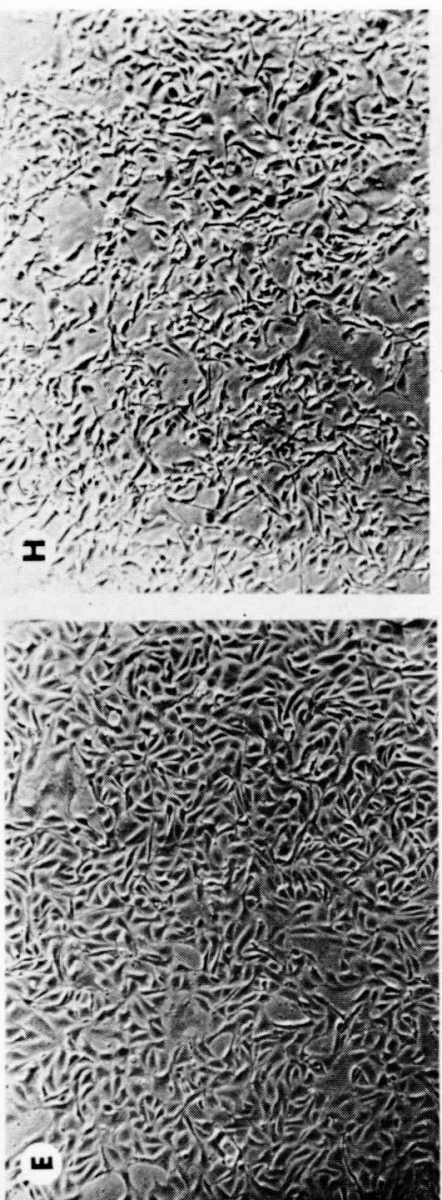

Cy $-310010$ S) in $=0,0$

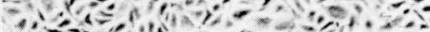
(X)

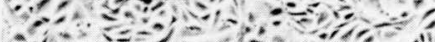
将, =

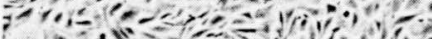
(3-

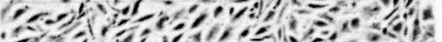
(1) 1 1) 102010

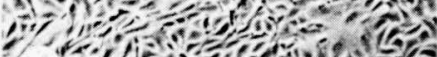
$+\infty$ r
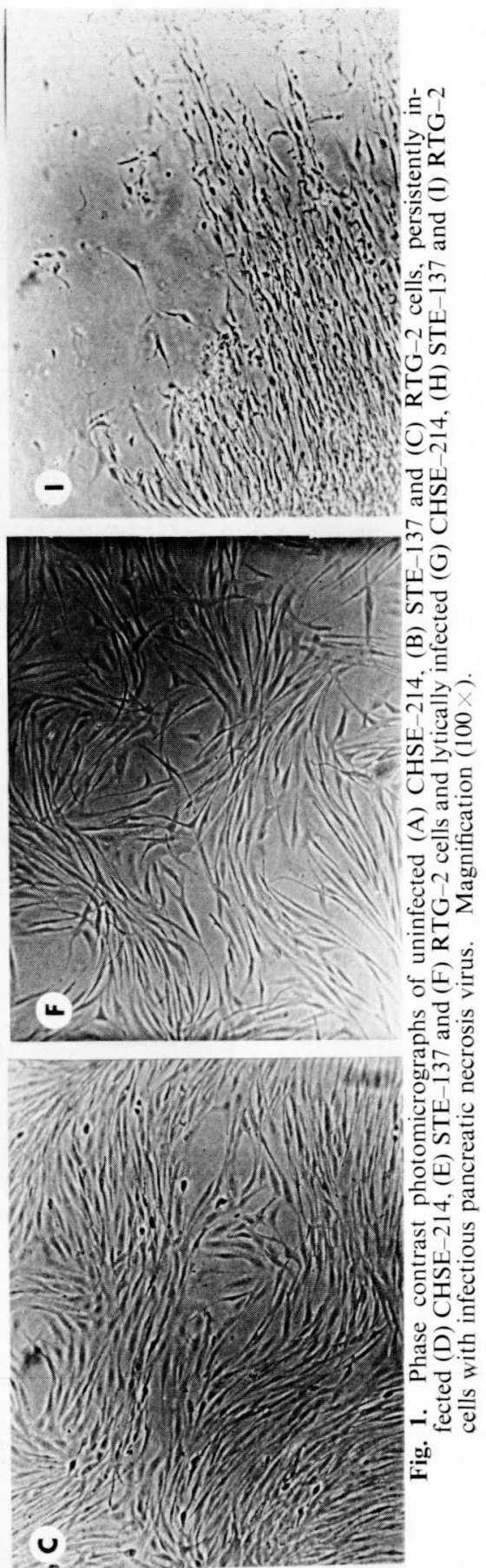

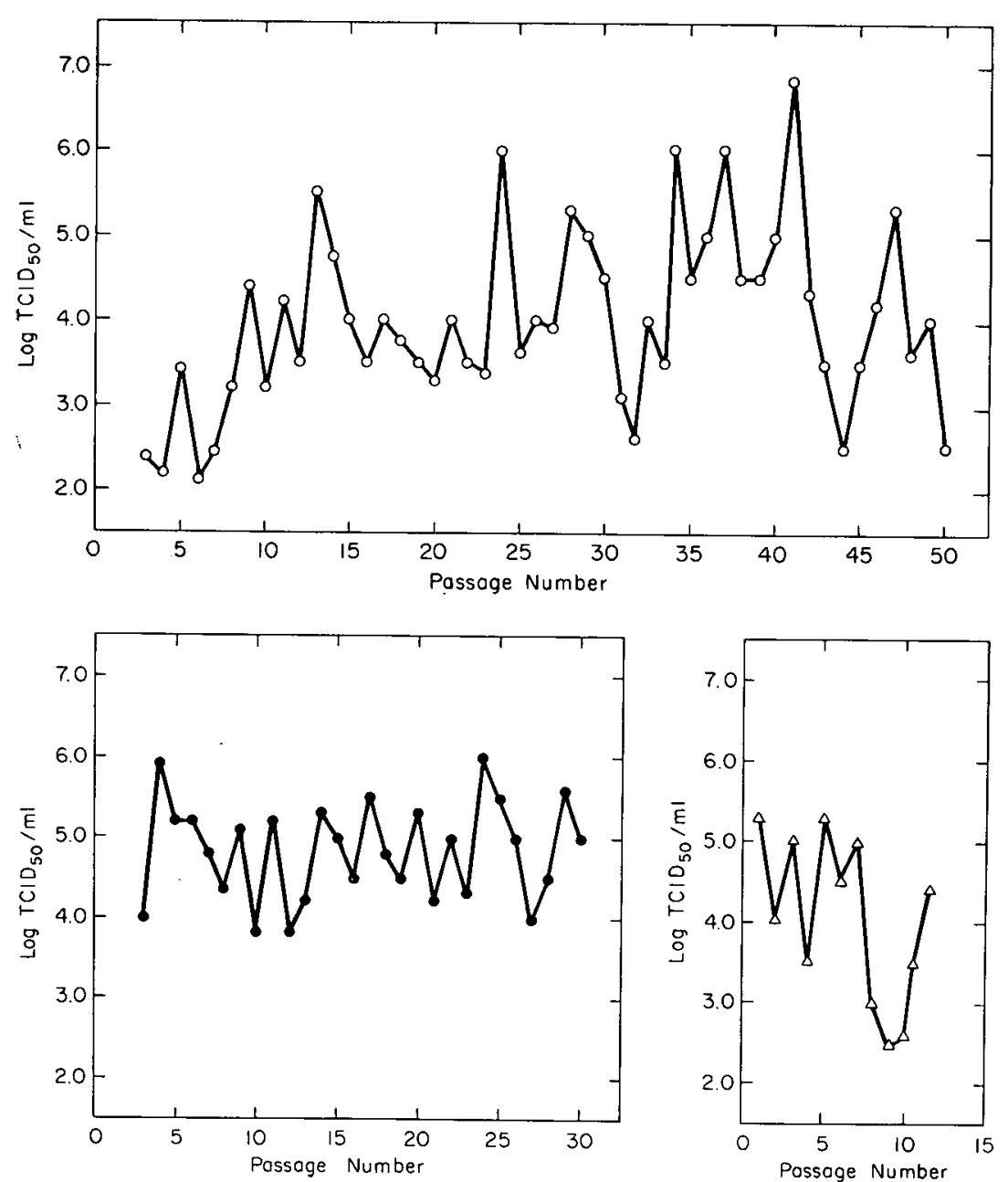

Fig. 2. Concentrations of infectious virus released from $(O-O)$ STE-137, (- - CHSE-214 and $(\triangle-\Delta)$ RTG-2 cell lines persistently infected with infectious pancreatic necrosis virus. Virus concentrations in the culture fluids were determined prior to weekly subcultures $(1: 3)$ of persistently infected cell lines.

$16^{\circ} \mathrm{C}$ and all lines were subcultured (1:3 split) at approximately 7 day intervals.

\section{Release of Infectious Virus}

Infectious virus was detected in the culture fluids of all three PI cell lines at each subculture. The concentrations of infectious virus at each passage are shown in Fig. 2. Infectious virus produced by the PI STE-137 line fluctuated from $10^{2.0}$ to $10^{8.8}$ $\mathrm{TCID}_{50} / \mathrm{m} l$ over approximately a 1 year period. The PI RTG-2 line had a similar pattern of virus release to the STE-137 line but the highest con- centration of virus detected was $10^{5.3} \mathrm{TCID}_{50} / \mathrm{ml}$. The PI CHSE-214 line exhibited a more stable release of infectious virus with less fluctuation between passages. The concentrations of infectious virus in the culture fluids of the PI CHSE-214 cell line were always greater than $10^{3.8} \mathrm{TCID}_{50} / \mathrm{m} l$ but never more than $10^{8.0} \mathrm{TCID}_{50} / \mathrm{m} l$.

\section{Immunofluorescenve}

Viral antigens were detected in only a fraction ( $1 \%$ or less) of the cells in all three PI lines (Fig. 3). Cells containing IPNV antigens were usually in 

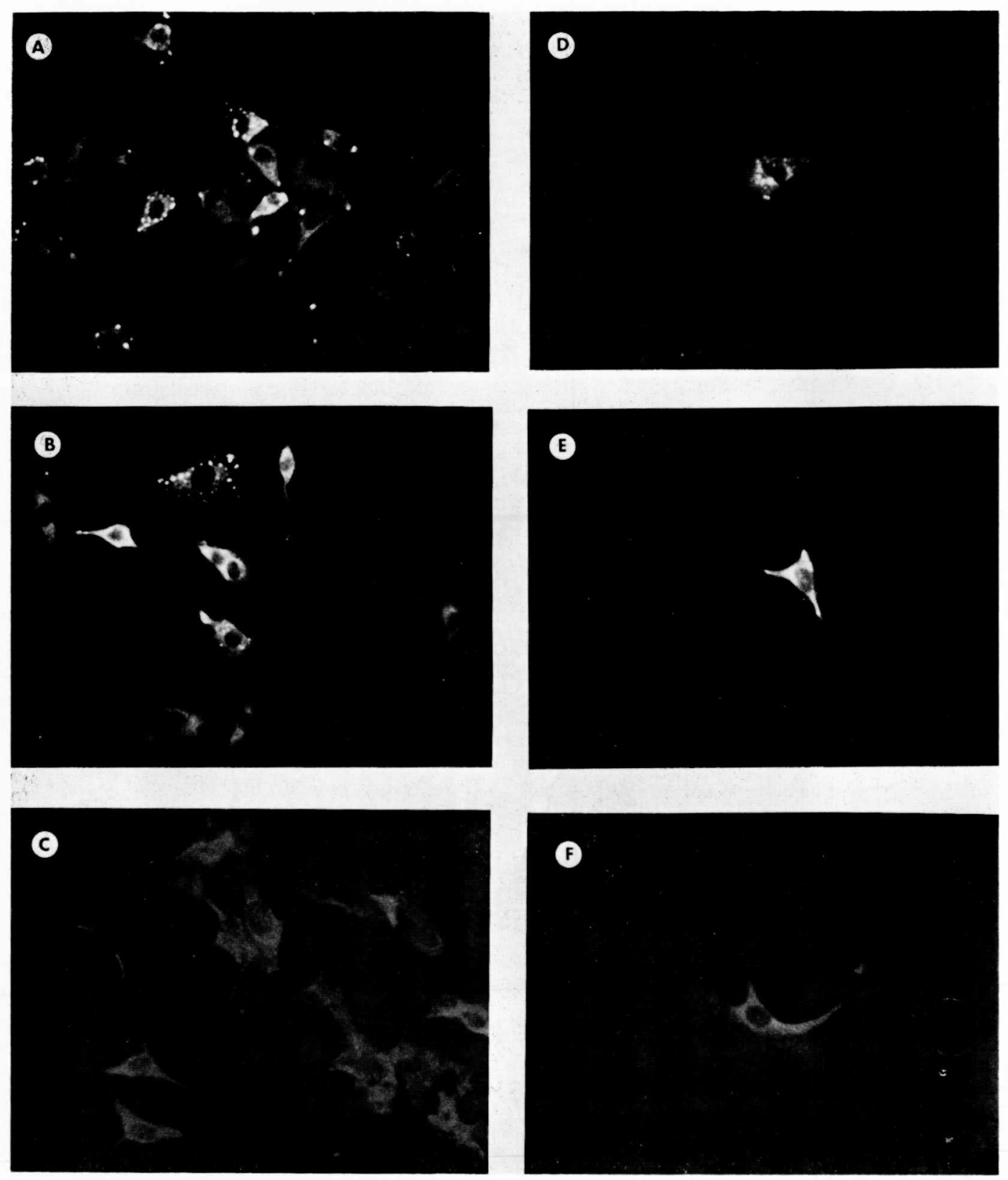

Fig. 3. Immunofluorescent photomicrographs of lytically infected (A) STE-137, (B) CHSE-214, (C) RTG-2 cells and persistently infected (D) STE-137, (E) CHSE-214 and (F) RTG-2 cells with infectious pancreatic necrosis virus. Magnification $(400 \times)$.

advanced stages of infection as determined by comparisons to control cells lytically infected with IPNV. Most of the cells in the PI line populations did not contain detectable levels of IPNV antigen and this staining pattern was not altered by high multiplicity infection with CL-IPNV.

\section{Susceptibility to Heterologous Viruses}

Persistently infected cell lines were challenged with Herpesvirus salmonis, CSV and IHNV to 
examine the specificity of superinfection resistance and to determine how efficiently heterologous virus plaqued on PI lines compared to normal lines. Although PI cell lines were resistant to challenges with IPNV (even serologically diverse strains) they were susceptible to infections with Herpesvirus salmonis, CSV and IHNV. The efficiency of plaquing of IHNV on PI cell lines is shown in Table 1. The plaquing efficiency of IHNV on PI CHSE-214 and STE-137 cells approached that of normal cells. The PI RTG-2 line was only $32 \%$ as efficient in plaquing IHNV when compared to control cells.

Table 1. Plaquing efficiency of infectious hematopoietic necrosis virus on normal cell lines compared to those persistently infected with infectious pancreatic necrosis virus

\begin{tabular}{lccc}
\hline \multicolumn{3}{c}{ Titer IHNV $^{\mathrm{a}}(\mathrm{PFU} / \mathrm{m} l)$} \\
\hline Cell Line & $\begin{array}{c}\text { Persistently } \\
\text { Infected } \\
\text { Cells }\end{array}$ & $\begin{array}{c}\text { Control } \\
\text { Cells }\end{array}$ & $\begin{array}{c}\text { Plaque } \\
\text { Efficiency } \\
(\%)\end{array}$ \\
\hline CHSE-214 & $7.5 \times 10^{6}$ & $8.0 \times 10^{6}$ & 94 \\
STE-137 & $1.9 \times 10^{7}$ & $2.2 \times 10^{7}$ & 86 \\
RTG-2 & $2.6 \times 10^{6}$ & $8.2 \times 10^{6}$ & 32 \\
\hline
\end{tabular}

a Infectious hematopoietic necrosis virus (IHNV) was adsorbed to monolyers of PI lines and control cells for $1 \mathrm{~h}$ and then overlayed with MEM-5 plus $1 \%$ methylcellulose. The titers of IHNV are expressed as the average of duplicate titrations.

b The plaquing efficiency is expressed as the value obtained by dividing the plaque titer of IHNV on PI cells by the titer obtained on control cells $\times 100$.

\section{Interferon Production}

The culture fluids from all three PI cells were assayed for interferon activity by plaque reduction of IHNV (Table 2). Activity indicating interferon was not detected in the culture fluids of the PI CHSE-214 or STE-137 lines. In contrast, culture fluids from PI RTG-2 cells had an inhibitory effect on the plaque titer of IHNV compared to fluids from control cells. This activity was presumed to be a result of the stimulation of treated cells by interferon present in the culture fluids of PI RTG-2 cells.

\section{Temperature Effects}

The effect of propagating PI CHSE-214 and STE-137 lines at 16 and $22^{\circ} \mathrm{C}$ are shown in Table 3 .
Table 2. Determinations to detect interferon in the culture fluids of normal and cell lines persistently infected with infectious pancreatic necrosis virus by reducing the plaque titer of infectious hematopoietic necrosis virus

\begin{tabular}{lc}
\hline Source of Culture Fluid $^{\mathrm{a}}$ & Titer IHNV $^{\mathrm{b}}$ \\
\hline STE-137/CL-IPNV & $1.7 \times 10^{8}$ \\
STE-137/Normal & $2.0 \times 10^{8}$ \\
CHSE-214/CL-IPNV & $1.5 \times 10^{6}$ \\
CHSE-214/Normal & $4.0 \times 10^{8}$ \\
RTG-2/CL-IPNV & $6.5 \times 10^{4}$ \\
RTG-2/Normal & $1.6 \times 10^{8}$ \\
\hline
\end{tabular}

a Control CHSE-214, STE-137 and RTG-2 cells were treated with culture fluids from persistently infected or uninfected cell lines for 12-24 h and then challenged with infectious hematopoietic necrosis virus.

b Expressed as PFU $/ \mathrm{m} /$ of culture medium.

The production of infectious virus detected in the culture fluids of PI lines was approximately the same at both 16 and $22^{\circ} \mathrm{C}$. Furthermore the virus produced by PI lines at both temperatures demonstrated a similar sensitivity $(0.02-0.32)$ when titrated at 16 and $22^{\circ} \mathrm{C}$. Stock CL-IPNV used to establish persistent infections showed similar increases in replication at $16^{\circ}$ compared to $22^{\circ} \mathrm{C}$. These results indicate that appreciable changes in the temperature sensitivity of CL-IPNV (released from PI lines after many passages) had not occurred when compared to stock CL-IPNV used to initiate these persistent infections.

\section{Autointerference}

During the titrations of culture fluids from the PI STE-137 and RTG-2 cell lines it was observed that undiluted $\left(10^{\circ}\right)$ or low dilutions $\left(10^{-1}\right)$ induced little or no CPE in control cells. Higher dilutions $\left(10^{-2}\right.$ to $\left.10^{-5}\right)$ of the same inoculum resulted in extensive CPE. The yields of infectious virus from control cells treated with undiluted or diluted culture fluids from PI STE-137, RTG-2 and CHSE214 cells are shown in Table 4.

Autointerference was never observed during the titrations of virus in the culture fluids from PI CHSE-214 cells and correspondingly there were no differences in virus yields between control cells inoculated with undiluted and diluted virus. Autointerference was observed with virus from both PI RTG-2 and STE-137 lines and the dif- 
Table 3. Titers of infectious virus released into the culture fluids from cell lines persistently infected with infectious pancreatic necrosis virus following propagation at 16 and $22^{\circ} \mathrm{C}$ for 9 days

\begin{tabular}{|c|c|c|c|c|c|c|}
\hline Cell Line & $\begin{array}{c}\text { Passage } \\
\text { No. }\end{array}$ & $\begin{array}{c}\text { Cell } \\
\text { Numbers }\end{array}$ & $\begin{array}{c}\text { Temp }{ }^{\circ} \mathrm{C} \\
\text { Cells } \\
\text { Propagated }\end{array}$ & $\begin{array}{l}\text { Temp }{ }^{\circ} \mathrm{C} \\
\text { of Assay }\end{array}$ & Titer $^{2}$ & $\begin{array}{c}22 / 16^{\circ} \mathrm{C}^{\mathrm{b}} \\
\text { ratio }\end{array}$ \\
\hline \multirow[t]{2}{*}{$\begin{array}{l}\text { STE-137/ } \\
\text { CL-IPNV }\end{array}$} & P41 & $6.6 \times 10^{5}$ & 16 & $\begin{array}{l}16 \\
22\end{array}$ & $\begin{array}{l}10^{4.6} \\
10^{3.1}\end{array}$ & 0.03 \\
\hline & & $6.7 \times 10^{5}$ & 16 & $\begin{array}{l}16 \\
22 \\
16 \\
22\end{array}$ & $\begin{array}{l}10^{4.3} \\
10^{2.6} \\
10^{3.8} \\
10^{3.1}\end{array}$ & 0.32 \\
\hline \multirow[t]{2}{*}{$\begin{array}{l}\text { CHSE-214/ } \\
\text { CL-IPNV }\end{array}$} & $\mathrm{P} 21$ & $1.8 \times 10^{8}$ & 22 & $\begin{array}{l}16 \\
22\end{array}$ & $\begin{array}{l}10^{3.6} \\
10^{2.1}\end{array}$ & 0.03 \\
\hline & & $1.2 \times 10^{6}$ & 16 & $\begin{array}{l}16 \\
22\end{array}$ & $\begin{array}{l}10^{7.5} \\
10^{7.1}\end{array}$ & 0.41 \\
\hline $\begin{array}{l}\text { CL-IPNV } \\
\text { CONTROL } \\
\text { CHSE-214 }\end{array}$ & & $2.5 \times 10^{8}$ & 22 & $\begin{array}{l}16 \\
22\end{array}$ & $\begin{array}{l}10^{7.7} \\
10^{7.8}\end{array}$ & 0.79 \\
\hline $\begin{array}{l}\text { CL-IPNV' } \\
\text { Control } \\
\text { STE-137 }\end{array}$ & & $1.0 \times 10^{8}$ & 16 & $\begin{array}{l}16 \\
22\end{array}$ & $\begin{array}{l}10^{7.3} \\
10^{7.1}\end{array}$ & 0.63 \\
\hline & & $1.2 \times 10^{8}$ & 22 & $\begin{array}{l}16 \\
22\end{array}$ & $\begin{array}{l}10^{7.5} \\
10^{7.0}\end{array}$ & 0.32 \\
\hline
\end{tabular}

a Standardized to $\mathrm{TCID}_{50}$ per $10^{8}$ cells. Each value represents the geometric mean of duplicate titrations.

b Expressed as the ratio of virus titer at 22 compared with $16^{\circ} \mathrm{C}$.

c Titers of infectious virus released into the culture fluids were determined after 3 days.

Table 4. Yields of infectious virus from cells inoculated with undiluted and diluted culture fluids of STE-137, CHSE-214 and RTG-2 cells persistently infected with infectious pancreatic necrosis virus

\begin{tabular}{|c|c|c|c|c|c|}
\hline Source of Culture Fluid & Passage No. & Dilution $^{\mathrm{a}}$ & $\mathrm{CPE}$ & Yield $^{\mathrm{b}}$ & $\begin{array}{l}\text { Ratio Diluted/ } \\
\text { Undiluted }\end{array}$ \\
\hline \multirow[t]{8}{*}{ STE-137/CL-IPNV } & P29 & $10^{0}$ & - & $10^{\overline{5} .5}$ & \\
\hline & & $10^{-2}$ & + & $10^{8.7}$ & 1,585 \\
\hline & P34 & $10^{\circ}$ & - & $10^{6.0}$ & \\
\hline & & $10^{-1}$ & - & $10^{5.5}$ & 0.32 \\
\hline & & $10^{-2}$ & & $10^{8.0}$ & 100 \\
\hline & & $10^{-5}$ & + & $10^{8.7}$ & 501 \\
\hline & P46 & $10^{\circ}$ & - & $10^{5.8}$ & \\
\hline & & $10^{-2}$ & + & $10^{9.0}$ & 1,585 \\
\hline \multirow[t]{2}{*}{ CHSE-214/CL-IPNV } & P25 & $10^{\circ}$ & + & $10^{9.0}$ & \\
\hline & & $10^{-2}$ & + & $10^{9.1}$ & 1 \\
\hline \multirow[t]{3}{*}{ RTG-2/CL-IPNV } & P 3 & $10^{0}$ & - & $10^{3.8}$ & \\
\hline & & $10^{-2}$ & - & $10^{5.8}$ & 100 \\
\hline & & $10^{-4}$ & + & $10^{8.7}$ & 79,432 \\
\hline
\end{tabular}

a Cell culture fluids from STE-137/CL-IPNV cultures were applied directly or following 10-fold dilution in MEM-10 to cells in 96 well dishes.

b Expressed as $\log _{10} \mathrm{TCID}_{50} / \mathrm{m} l$. 
ference in virus yields from cells treated with undiluted or diluted virus was as great as $10^{4} \mathrm{TCID}_{50}$.

Autointerference was also observed if the culture fluids from PI STE-137 cells were centrifuged $(100,000 \times g)$ for $1 \mathrm{~h}$ and the resulting pellet resuspended in MEM-5 at one tenth the original volume. Interference of equal magnitude was observed with culture fluids from PI STE-137 and RTG-2 cell lines when titrations were performed on homologous cell lines (STE-137 and RTG-2) or heterologous cell lines (CHSE-214).

\section{Treatment of PI Cell Lines with Anti-IPNV Rabbit Serum}

Persistently infected STE-137 and CHSE-214 cells were propagated in MEM-10 containing antiIPNV rabbit serum $(1: 50)$ to determine if the diffusion of virus or viral products between cells was required for the maintenance of persistent infection. Three subcultures in MEM-10 containing antibody followed by a single subculture in MEM-10 without antibody resulted in a spontaneous induction of cytopathic effect (CPE) involving nearly all the cells in the culture. If PI lines were propagated for seven or more consecutive subcultures in MEM-10 containing antibody, persistent infection was cured. The culture fluids from these cured lines were monitored for eight additional passages in MEM-10 (no antibody) without the detection of any released virus. In addition these cured lines were devoid of viral antigens (as determined by immuno-fluorescence) and were susceptible to IPNV infections as were uninfected control cells propagated under identical conditions. Persistently infected STE-137 and CHSE-214 cell lines propagated in MEM-10 containing normal rabbit serum (1:50) and treated in the same manner remained infected as demonstrated by infectious virus release and resistance to superinfection.

\section{Discussion}

Persistent infections were established with the same strain (CL) of IPNV in three cell lines derived from salmonid tissues. By using the same strain of IPNV it was possible to compare the contribution that different host cells made to the nature of persistent infection.

All three cell lines were characterized by (1) continuous releases of infectious virus (2) resistance to superinfection (even to serologically diverse strains of IPNV), (3) susceptibility to infection with heterologous viruses and (4) the presence of IPNV antigens detected by immunofluorescence.

The concentrations of virus released by PI cell lines fluctuated from $10^{2.0}$ to $10^{8.8} \mathrm{TCID}_{50} / \mathrm{m} l$, well below the levels $\left(10^{9.0} \mathrm{TCID}_{50} / \mathrm{m} l\right)$ which accompanied lytic infections. This results from the replication of IPNV in only a fraction of the cells in the population as determined by immunofluorescent tests and infectious center assays HEDRICK et al., 1981).

The small number of cells producing IPNV in PI lines suggested that their selective removal would terminate infection. This was accomplished by propagations of PI CHSE-214 and STE-137 cells in growth medium containing rabbit anti-IPNV serum. This indicated that the maintenance of persistence in these lines was dependent on the diffusion of virus or viral products between cells in the population rather than between parent and daughter cells during division.

Both PI CHSE-214 and STE-137 cell lines did not produce detectable levels of interferon. Similar observations were made by MACDONALD and KenNedy (1979) with CHSE-214 cells PI with IPNV. They also found that normal CHSE214 cells were defective in interferon production in response to lytic infections with IPNV. In contrast, the RTG-2 cell line is known to release interferon under lytic conditions with both IPNV and IHNV (DeSeNA and RIO, 1975). Activity indicating the presence of interferon was found in the culture fluids of PI RTG-2 cells. The production of interferon during viral persistence in this cell line may explain the reduced plaquing efficiency of IHNV compared to control RTG-2 cells.

The selection of temperature-sensitive mutants in mammalian cells PI with VSV (Younger et al., 1976), reovirus (AHMEd and Graham, 1977) and Newcastle disease virus (Preble and YOUNGNER, 1975) have been shown to be important in the maintenance of persistence. In their studies the parent strains used to initiate persistent infection were rapidly (passage 4 to 8 ) replaced by ts mutants that were unable to replicate at restrictive temperatures $\left(39.5 / 32^{\circ} \mathrm{C}\right.$ ratio $\left.=10^{-4}\right)$. An examination of virus produced by PI STE-137 (passage 41) and CHSE-214 (passage 21) cells revealed 
that the $22 / 16^{\circ} \mathrm{C}$ ratios were only approximately tenfold $\left(10^{-1}\right)$ those observed with stock CLIPNV used to initiate persistent infections. These results make it difficult to ascribe an important role for ts mutants in the persistent infection of these salmonid cell lines with IPNV.

The autointerference observed in titrations of the culture fluids of PI STE-137 and RTG-2 cell lines was similar to that reported by NicHOLSON and Dunn (1974) and Macdonald and Yamamoto (1978). They found that repeated high multiplicity passages of IPNV in RTG -2 and CHSE-214 cells resulted in homologous viral interference. Interference was characterized by reductions in both CPE and infectious virus production. Both groups concluded that interference was a manifestation of the production of defective interfering (DI) virus. The autointerfering component produced by PI STE-137 cells has been isolated by isopycnic centrifugation in cesium chloride (Hedrick et al., 1978b). This component had a bouyant density of $1.29 \mathrm{~g} / \mathrm{cc}$ compared to $1.33 \mathrm{~g} / \mathrm{cc}$ for infectious virus also produced by these cells. The concurrent production of DI with infectious virus was proposed as a mechanism which protected the majority of cells in the persistent population from lytic infection (a continuous state of autointerference). Additional evidence for DI virus production by PI STE-137 cells was obtained by electron microscopy (Hedrick et al., 1981). A similar role for DI virus in PI RTG-2 cells is suggested by the autointerference observed while titrating the virus released in the culture fluids of this line. The release of interferon by PI RTG-2 cells may also function, and perhaps cooperatively, with DI IPNV in preventing the cytocidal effects of infectious virus.

Although PI CHSE-214 cells share certain characteristics with PI RTG-2 and STE-137 cells, autointerference has never been observed during the titration of virus in the culture fluids of this line. It was therefore difficult to estimate the functions of DI IPNV in this cell line. It was apparent that PI CHSE-214 cells effectively regulated infectious virus (as demonstrated by less fluctuation in virus concentrations between passages compared to PI RTG-2 or STE-137 cells) but the mechanism(s) have not been determined. If DI virus mediates the persistence in PI CHSE-214 cells the properties were different than those produced by PI STE-137 or RTG-2 cells. It is possible that a mechanism unique to this cell line is involved in maintaining viral persistence.

The difference in the nature of viral persistence in these three cell lines emphasizes the importance of the cells' contribution in this host-parasite relationship. At least two mechanisms (interferon and DI virus production) functioning alone or cooperatively spare PI cell lines from the cytocidal effects of infectious virus. A similar diversity in the response of different fish species to IPNV infection might be expected. Therefore these PI cell lines may be useful models in predicting the range of host cell-virus interactions that may result from IPNV infection in salmon and trout. The similarities between these cell lines and the carrier state in brook trout are the subject of a previous report (HEDRICK et al., 1980).

\section{Acknowledgements}

This work was supported by a grant from the Oregon Department of Fish and Wildlife under the Anadromous Fish Act (PL-89304). The authors wish to thank Dr. J. C. Leong for her helpful comments concerning this manuscript. We also aknowledge the contribution made by the National Science Foundation U.S.-Taiwan Cooperative Grant No. INT-7909344. Oregon Agricultural Experiment Station Technical Paper No. 5636.

\section{Bibliography}

Ahmed, R. and A. F. Graham (1977): Persistent infection in $\mathbf{L}$ cells with temperature-sensitive mutants of reovirus. J. Virol., 23, 250-262.

Ahne, W. (1977): Persistent infection in CHSE-214 cells with IPN virus isolated from pike (Esox lucius). Bull. Off. Int. Epiz. 87, 415-416.

Billi, J. L. and K. Wolf (1969): Quantitative comparison of peritoneal washes and feces for detecting infectious pancreatic necrosis (IPNV) virus in carrier brook trout. J. Fish. Res. Board Can., 26 14591465.

DESena, J. and G. Rio (1975): Partial purification and characterization of RTG-2 fish cell interferon. Inf. Immun., 11, 815-822.

DoBos, P. (1976): Size and structure of the genome of infectious pancreatic necrosis virus. Nucleic Acids Res., 3, 1903-1924.

Fryer, J. L., A. Yusha and K. S. Pilcher (1965): 
The in vitro cultivation of tissue and cells of Pacific salmon and steelhead trout. Ann. N. Y. Acad. Sci., 126, 566-586.

Hedrick, R. P., J. C. LeONG and J. L. Fryer (1978a): Persistent infection by infectious pancreatic necrosis virus (IPNV) in piscine cells. Abstracts of the Annual Meeting, Am. Soc. Microbiol., S 334, 267.

Hedrick R. P., J. C. LeONG and J. L. Fryer (1978b): Persistent infections in salmonid fish cells with infectious pancreatic necrosis virus (IPNV). J. Fish. Dis., 1, 297-308.

Hedrick, R. P., J. C. LeONG and J. L. Fryer (1981): Persistent infection of salmonid cells with infectious pancreatic necrosis virus (IPNV): A model for the carrier state in trout. Aquaculture-Public Health, Regulatory and Management Aspects. Proceedings from a symposium sponsored by the U. S. Food and Drug Administration. February 12 through 14, 1980. New Orleans, Louisiana.

Huang, A. S. and D. Baltimore (1970): Defective viral particles and viral disease processes. Nature (London), 226, 325-327.

JoKLIK, W. K. (1977): Mechanisms of establishment and maintenance of persistent infections. SCHLESSINGER, D. ed., Microbiology, 1977. Am. Soc. Microbiol., Wash., D. C., 434-438.

Macdonald, R. D. and T. Yamamoto (1978): Quantitative analysis of defective interfering particles in infectious pancreatic necrosis virus preparations. Arch. Virol., 57, 77-89.

MACDONALD, R. D. and J. C. KenNedy (1979): Infectious pancreatic necrosis virus infects chinook salmon embryo cells independent of interferon. Virol., 95: 260-264.

MulCaHy, D. M. (1977): Distribution and epizootiology of infectious pancreatic necrosis and infectious hematopoietic necrosis viruses of salmonid fishes in Oregon. Ph. D. Thesis. Oregon State University, Corvallis, OR.

Nicholson, B. L. and J. DunN (1974): Homologous viral interference in trout and Atlantic salmon cell cultures infected with infectious pancreatic necrosis virus. J. Virol., 14, 180-182.

Preble, O. T. and J. S. Youngner (1975): Temperature-sensitive viruses and the etiology of chronic and inapparent infections. J. Inf. Dis., 131, 467-472.
Reno, P. W., S. Darley and M. Savan (1978): ' Infectious pancreatic necrosis: experimental induction of a carrier state in trout. J. Fish. Res. Board Can., 11, 1451-1456.

RimA, B. K. and S. J. Martin (1976): Persistent infection of tissue cultured cells by RNA viruses. Med. Microbiol. and Immun., 162, 89-118.

Sekellick, M. J. and P. I. Marcus (1978): Persistent infection I. Interferon-inducing defective interfering particles as mediators of cell sparing: possible role in persistent infection by vesicular stomatitis virus. Virol., 85, 175-186.

Simpson, R. W. and M. InNuma (1975): Recovery of infectious proviral DNA from mammalian cells infected with respiratory syncitial virus. Proc. Nat. Acad. Sci., 72, 3230-3234.

Tu, K. C., R. S. SPendlove and R. W. Goede (1974): Immunofluorescent cell assay of infectious pancreatic necrosis virus. Appl. Microbiol., 27, 593-599.

Wolf, K. and M. C. QuimBY (1962): Established eurythemic line of fish cells in vitro. Science, 135, 1065-1066.

Wolf, K. and M. C. Quimby (1973): Fish virology: Procedures and preparation of materials for plaquing fish viruses in normal atmosphere. Fish Disease Leaflet, 35, 1-13.

Wolf, K., R. W. Darlington, W. G. Taylor, M. C. Quimby and I. NAGABayashi (1978): Herpesvirus salmonis: Characterization of a new pathogen of rainbow trout. J. Virol., 27, 659-665.

WOLF, K. and J. A. MANN (1980): Poikiliothermic vertebrate cell lines and viruses. In vitro, 16, 168179.

Yamamoto, T. (1975): Frequency of detection and survival of infectious pancreatic necrosis virus in a carrier population of brook trout (Salvelinus fontinalis) in a lake. J. Fish. Res. Board Can., 32, 568570.

Youngner, J. S. and E. J. Dubovi, D. O. Quagliano, M. Kelley and O. T. Preble (1976): Role of temperature-sensitive mutants in persistent infections initiated with vesicular stomatitis virus. J. Virol., 19, 90-101.

ZhADNOV, V. M. (1975): Integration of viral genomes. Nature (London), 256, 471-473. 